*ak RMIS View/Frint Document Cover Sheet tow

This document was retrieved from the Documentation and Records Manaqement (DRM) ISEARCH System. It is intended for Information only and may not be the most recent or updated version. Contact a Document Service Center (see Hanford Info for locations) if you need additional retrieval information.

Accession \#: D196013267

Document \#: SD-SNF-DP-006

Title/Desc:

105K EAST SANDFILTER BACKWASH LINE SAMPLE ANALYSIS REPORT 3RD CAMPAIGN

Pages: 33 


2. To: (Recaiving Organization)
Distribution

5. Proj./Prog./Dept./Div.:

105-K East Sandfilter

Backwash Line/Spent Nuclear

Fue 1s/PPC/AS

\section{Originator Remarks:}

This document is being released into the supporting document system for retrievability purposes.

11. Receiver Remarks:

For release.

\section{From: (Originating Organization) Production Planning and Control}

6. Cog. Engr.:

George L. Miller
4. Related EDT NO.:

$N / A$

7. Purchase Order No.:

$\mathrm{N} / \mathrm{A}$

9. Equip./Component No.:

$N / A$

10. System/Bldg./Facility:

$\mathrm{N} / \mathrm{A}$

12. Major Assm. Dwg. No.:

$N / A$

13. Permit/Permit Application No.: $N / A$

14. Required Response Date: $12 / 20 / 95$

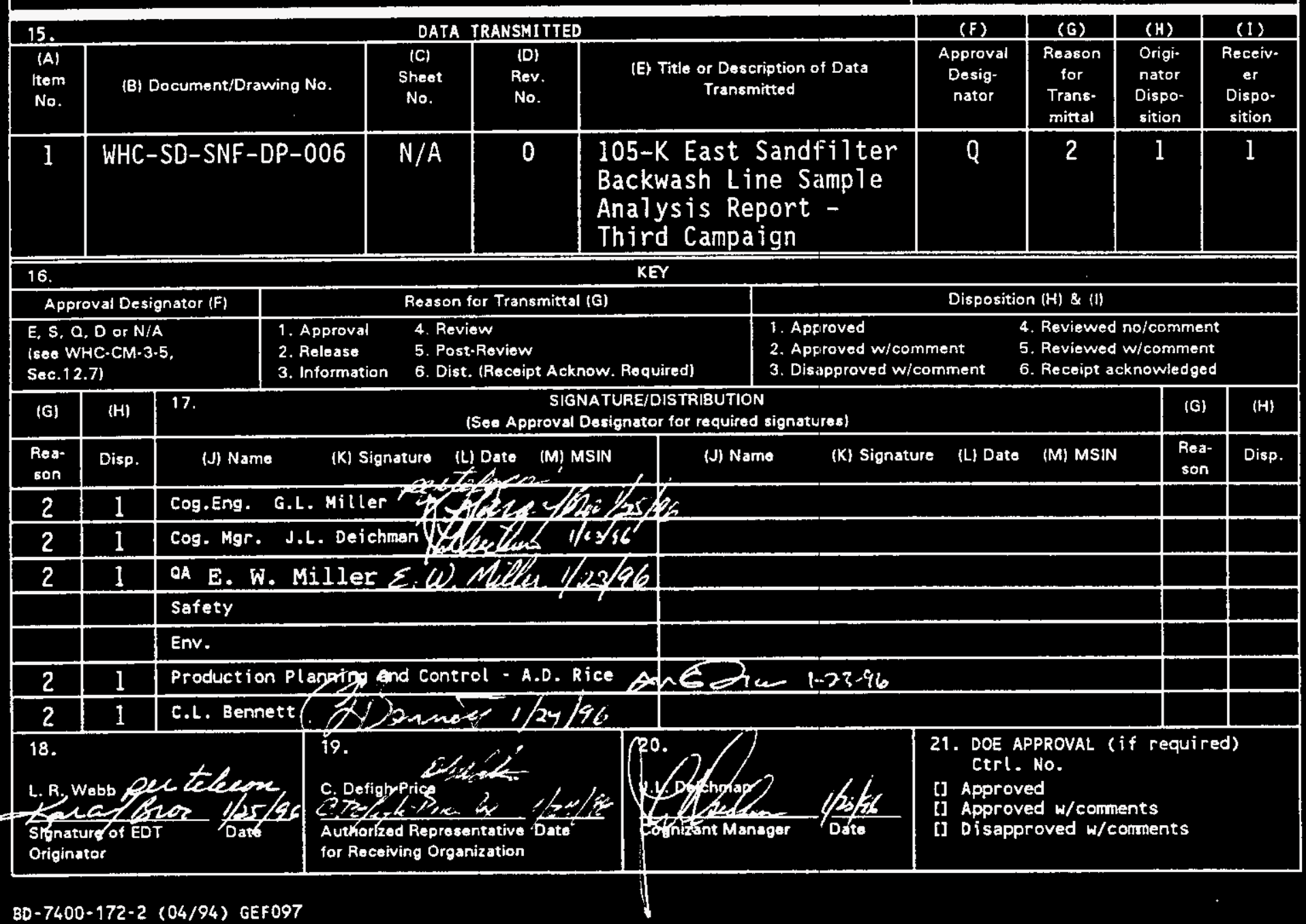




\title{
105-K East Sandfilter Backwash Line Sample Analysis Report - Third Campaign
}

\author{
George L. Miller \\ Westinghouse Hanford Company, Richland, WA 99352 \\ U.S. Department of Energy Contract DE-AC06-87RL10930 \\ EDT/ECN: 614765 UC: 2070 \\ Org Code: 75725 Charge Code: MD378 \\ B\&R Code: EW 3120074 Total Pages: $3 i^{\circ}$ \\ Key Words: 105-KE, 105-K, Sandfilter, Backwash, Line, Sample, Analysis, \\ Report, Third Campaign \\ Abstract: $\quad \mathrm{N} / \mathrm{A}$
}

TRADEMARK DISCLAIMER. Reference herein to any specific commercial product, process, or service by trade name, tradenark, manufacturer, or otherwise, does not necessarily constitute or imply its endorsement, recommendation, or favoring by the United States Government or any agency thereof or its contractors or subcontractors.

Printed in the United States of America. To obtain copies of this document, contact: WHC/BCS Document Control Services, P.0. Box 1970, Mai lstop 16-08, Richlapd WA 99352, Phone (509) 372-2420; Fax (509) 376-4989.
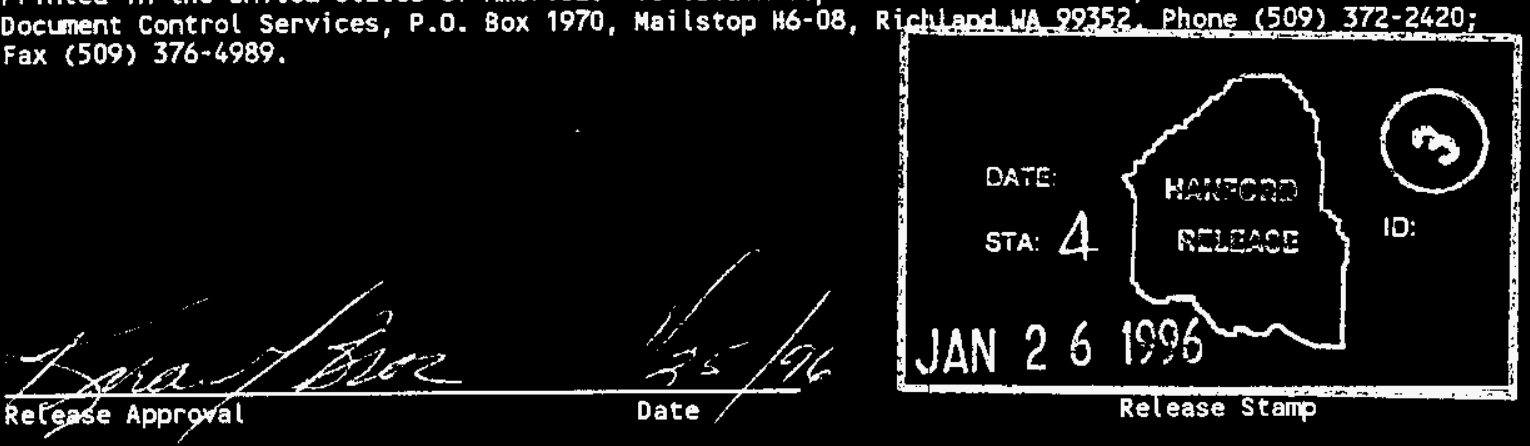

\section{Approved for Public Release}


WHC-SD-SNF-DP-006, REV. 0

ANALYTICAL SERVICES

105-K EAST SANDFILTER BACKWASH LINE SAMPLE ANALYSIS REPORT - THIRD CAMPAIGN

Project Coordinator: GEORGE L. MILLER

Prepared for the U.S. Department of Energy

Office of Environmental Restoration and Waste Management

by

Westinghouse Hanford Company

Box 1970 
WHC-SD-SNF-DP-006, REV。 0

TABLE OF CONTENTS

1.0 Introduction ................... 1

2.0 Sample Preparation ................ 1

2.1 Appearance and Dose Rates .............. 1

2.2 Sludge Settling.................. 1

2.3 Sample Preparation ................ 1

2.4 Residues .................. 2

3.0 Results .................... 2

3.1 Sample Preparation Results .............. 2

3.2 Radiochemical Results ................ 4

3.3 Auxiliary Results ............... 4

4.0 References .................. 8

Appendix A - K-East Basin Sand Filter Backwash Line Campaign II . . . . . 13

Appendix B - Chain of Custody Form . . . . . . . . . . . 15

Appendix C - Letter of Instruction . . . . . . . . . 17

This document consists of pages 1 through 27. 


\author{
WHC-SD-SWF-DP-006.REV. 0 \\ 105-K EAST SANDFILTER BACKWASH LINE SAMPLE ANALYSIS REPORT \\ THIRD CAMPAIGN \\ D. B. Bechtold
}

\title{
1.0 INTRODUCTION
}

This project seeks to produce uranium (U) and plutonium (Pu) analyses of samples taken from the KE basin filter backwash line each time the sand filter is backwashed. $K$ Basin operations will use the analytical results to determine additions of fissile materials to the backwash sludge pit and thereby maintain a running inventory of fissile elements in the pit. $K$ Basin operations must not exceed a certain total inventory in order to be within a criticality specification.

The third campaign of this project consisted of three samples, numbered by the customer 245KEB, 246KEB, and 247KEB. A revised letter of instruction controlled their processing (Reference 4.1).

\subsection{SAMPLE PREPARATION}

All work on the samples except the actual analysis of digests is recorded in controlled laboratory notebook WHC-N-341-2, pages 129-134.

\subsection{Appearance and Dose Rates.}

All three samples arrived in $250 \mathrm{~mL}$ jars virtually full of clear water, with a very small amount of brown, flocculent sludge lying on the bottom -- not enough to cover the bottom. Over-the-Top Reading (OTR) dose rates are included in the Sample Preparation Data Sheet.

\subsection{Sludge Settiing.}

Because so little sludge was present in each sample, no attempts at sludge volume or mass determinations were made. Each jar was merely marked at the total sample level, then allowed to settle for 24 hours before proceeding. The sludge settled well, leaving clear, excess water.

\subsection{Sample Preparation.}

Due to complete settling, the excess water was pipetted off each sample before the sludge contents of each sample were transferred individually to PTFE drying/digestion beakers. No excess water was submitted for total alpha analysis, since this was not requested on the chain of custody. The cleaned sample jars were 
tared, then weighed with laboratory water to the total sample (water) level marks.

Each sample was dried in a PTFE beaker with a PTFE watchglass 7 id and PTFE standoffs on a hot plate to yield in all cases dark brown material like broken up dried mud. All samples yielded less than $0.3 \mathrm{gram}$ each of dried sludge; therefore, all sludges were digested and no excess sludge was archived.

Each sample was digested twice with approximately $50 \mathrm{~mL}$ of acid that was approximately $5 \mathrm{M}$ each in nitric and hydrochloric acids, and 3 drops concentrated HF, for four hours. Digestates were separated from residues by decantation/rinsing/centrifugation and placed into $500 \mathrm{~mL}$ volumetric flasks for dilution to known volume. Samples from each diluted digestate were submitted for total $U$ analysis, $\mathrm{Pu}^{238}$ analysis and $\mathrm{Pu}^{239,240}$ analysis. The remaining digestates were archived.

\subsection{Residues}

The undigested residues for each sample were dried to constant weight in the digesters, weighed and observed. There was very little residue in any sample (less than $200 \mathrm{mg}$ in all cases). The residues appeared to consist of tiny black bits.

\subsection{RESULTS}

\subsection{Sample Preparation Results}

The sample preparation datasheet appears as Table 1, where the procedural steps are described in Reference 4.1. All data precision and accuracy requirements for sample preparation listed in the letter of instruction (LOI) (Reference 4.1) were judged to have been met, except for steps to measure sludge weight and volume, which were not performed due to insufficient sludge. 
WHC-SD-SNF-DP-006 REV. 0

\begin{tabular}{|c|c|c|c|c|c|}
\hline & PARAMETER DESCRIPTION & UNITS & \multicolumn{3}{|c|}{ SAMPLE RESULTS } \\
\hline \multirow[t]{3}{*}{1} & Sample identity & & CUSTOMER NO. 245KEB & CUSTOMER NO. 246KEB & CUSTOMER NO. $247 \mathrm{KEB}$ \\
\hline & - amount of sludas & $\mathbf{m L}$ & 3 & 3 & 3 \\
\hline & contact dose tate & $\begin{array}{c}\text { mPad } \\
\text { or } \\
\text { mPlom }\end{array}$ & 2.5 & 2.5 & 2.0 \\
\hline 3 & Gross weight of sample bottle & $\mathbf{g}$ & 413.302 & 436.512 & 428.029 \\
\hline \multirow[t]{3}{*}{9} & $\begin{array}{c}\text { Not weight of excese water (if } \\
\text { requested) }\end{array}$ & $\mathbf{0}$ & $\mathrm{n} / \mathrm{a}$ & $n / a$ & $\mathbf{n} / \mathbf{a}$ \\
\hline & Not weight of laboratory woter sample & $\mathbf{g}$ & $n / a$ & $n / a$ & $\mathbf{n} / \mathbf{a}$ \\
\hline & water sample number & & $n / a$ & $n / a$ & $n / \mathbf{a}$ \\
\hline 10 & $\begin{array}{c}\text { Gross wt. of eample bottle w/o excess } \\
\text { water }\end{array}$ & a & $\mathrm{n} / \mathrm{a}$ & $n / a$ & $n / a$ \\
\hline 11 & $\begin{array}{c}\text { Tare weight of PTFE drying/digesting } \\
\text { vessel }\end{array}$ & $\boldsymbol{g}$ & 139.842 & $\uparrow 42.377$ & 140.544 \\
\hline 15 & Tare weight of sample bottle & q & 214.948 & 215.377 & 218.585 \\
\hline 17 & Weight of bottie filled to sludge mark & $\mathbf{q}$ & $n / a$ & $n / a$ & $n / a$ \\
\hline 19 & Wt. of bottla filled to initial liquid level & $\mathfrak{g}$ & 416.757 & 440.588 & 433.479 \\
\hline \multirow[t]{3}{*}{20} & Groses wt. of drying vessel, first drying & $\mathbf{g}$ & 139.904 & 142.605 & 140.685 \\
\hline & second drying & $\mathbf{9}$ & 139.904 & 142.604 & 140.686 \\
\hline & third drying & g & $\mathbf{n} / \mathbf{a}$ & $n / a$ & $n / a$ \\
\hline 24 & Net weight of excess dry solids & $\mathbf{g}$ & $\mathbf{0}$ & 0 & 0 \\
\hline 25 & Gross weight solids to be digested & $\mathbf{g}$ & 139.904 & 142.604 & 140.686 \\
\hline 40 & Volume of diluted digestate & $\mathbf{m L}$ & 500 & 500 & 500 \\
\hline \multirow[t]{3}{*}{44} & $\begin{array}{c}\text { Gross woight of dry digester plus } \\
\text { residue }\end{array}$ & $\mathbf{g}$ & 139.87 & 142.565 & 140.653 \\
\hline & 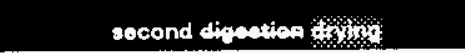 & $\mathbf{g}$ & 139.866 & 142.561 & 140.65 \\
\hline & third diquation of & $\mathbf{q}$ & $n / a$ & $\mathrm{n} / \mathrm{a}$ & n/a \\
\hline 46 & Appearance of dried residue & & Some minute black bits & Some minute black bits & Some minute black bits \\
\hline
\end{tabular}




\subsection{Radiochemical Results}

Table 2 includes the analytical laboratory radiochemical results for this, the third campaign.

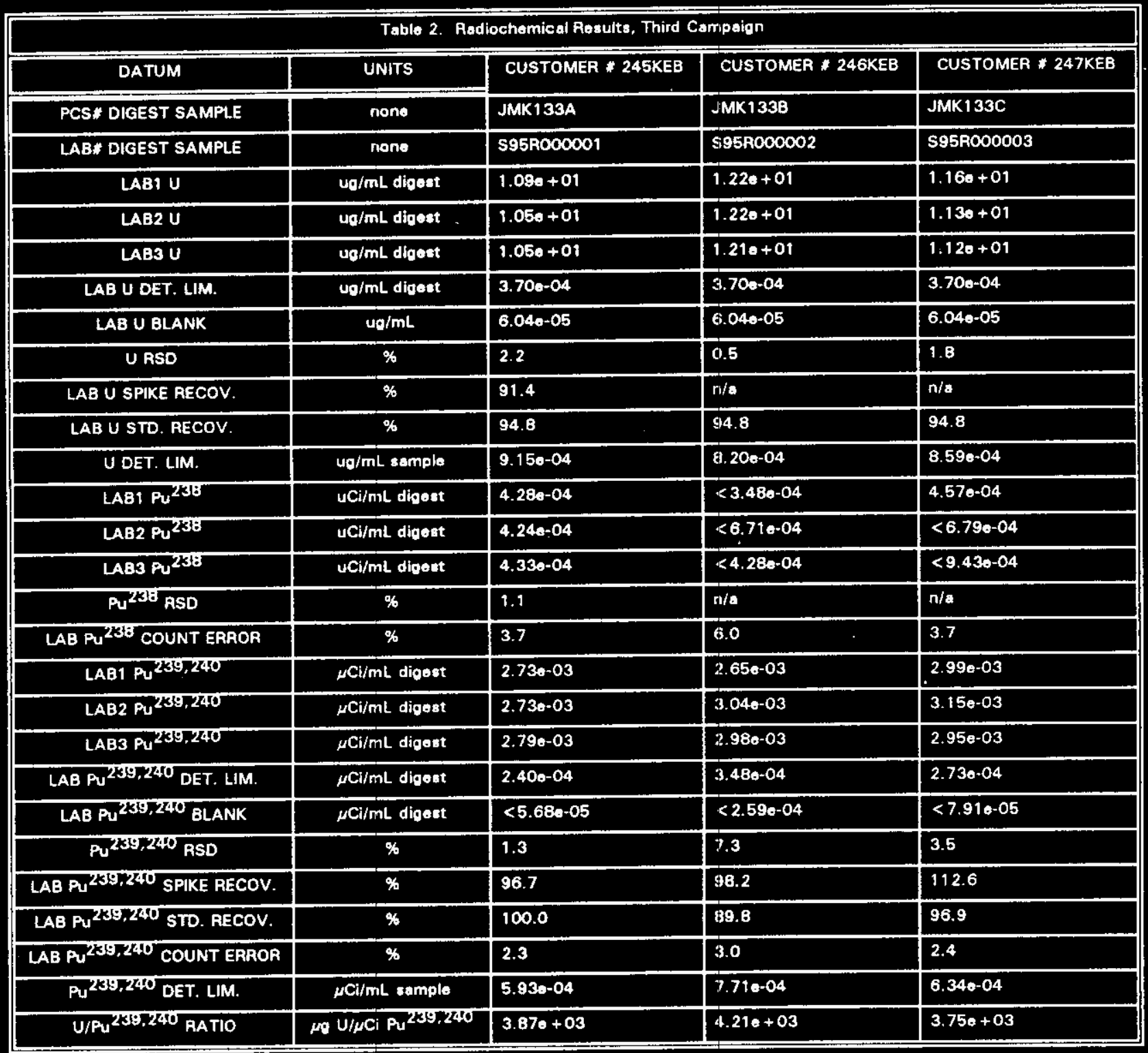

Examination of Table 2 reveals that all precision, accuracy and minimum detection limit requirements of the LOI Table 1 (Reference 4.1), when converted to comparable units, have been met for this campaign.

\subsection{Auxiliary Results}

Table 3 includes the complete third campaign results. It is presented as an aid to compare this campaign with previous ones. 
WHC-SD-SNF-DP-006 REV. 0

\begin{tabular}{|c|c|c|c|c|}
\hline DATUM & UNITS & CUSTOMER * 245KEB & CUSTOMER * 246KEB & CUSTOMER \# 247KEB \\
\hline CAMPAIGN & nono & THIFD & THIRD & THIRD \\
\hline - SLUDGE & $\mathrm{mL}$ & 3 & 3 & 3 \\
\hline DOSE RATE & mRad or mRem & 2.5 & 2.5 & 2 \\
\hline SLUDGE APPEARANCE & none & cloar water, brown floc & clear water, brown floc & clear water, brown floc \\
\hline GROSS SAMPLE JAR & a & 413.302 & 436.512 & 428.029 \\
\hline GROSS NO WATER & g & $n / a$ & $\mathrm{n} / \mathbf{0}$ & $n / a$ \\
\hline NET EXCESS WATER & a & $n / a$ & $n / a$ & $\mathrm{n} / \mathrm{a}$ \\
\hline TARE WATER SAMPLE & 0 & $n / \mathbf{a}$ & $n / \mathbf{a}$ & $n / a$ \\
\hline GAOSS WATER SAMPLE & 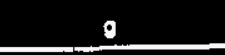 & $n / a$ & $\mathrm{n} / \mathrm{a}$ & $n / a$ \\
\hline NET WATER SAMPLE & $\mathfrak{g}$ & $n / 0$ & $n / a$ & $n / a$ \\
\hline PCS* WATER SAMPLE & none & $\mathbf{n} / \mathbf{a}$ & $n / a$ & $\mathrm{n} / \mathrm{a}$ \\
\hline LAB* WATER SAMPLE & nono & $\mathrm{n} / \mathrm{a}$ & $\mathrm{n} / \mathbf{a}$ & $n / a$ \\
\hline TARE DIGESTER & 9 & 139.842 & 142.377 & 140.544 \\
\hline TARE SAMPLE JAR & $\mathfrak{d}$ & 214.948 & 215.377 & 218.585 \\
\hline NET SLUDGE & $\mathfrak{0}$ & $n / \bullet$ & $n / a$ & $n / a$ \\
\hline GROSS SAMPLE JAR_TO_SLUDGE & a & $n / a$ & $\mathrm{n} / \mathrm{a}$ & $\mathrm{n} / \mathbf{a}$ \\
\hline GROSS SAMPLE JAR_TO_TOTAL & 은 & 416.757 & 440.588 & 433.479 \\
\hline VOLUME SAMPLE & $\mathrm{mL}$ & $2.020+02$ & $2.26 e+02$ & $2.15 a+02$ \\
\hline GROSS DRY IST & $\mathfrak{g}$ & 139,904 & 142.605 & 140.685 \\
\hline GROSS DRY 2ND & g & 139.904 & 142.604 & 140.686 \\
\hline GROSS DRY 3RD & 0 & $\mathrm{n} / \mathrm{a}$ & $n / a$ & $n / \mathbf{a}$ \\
\hline DRIES TO AVERAGE & none & 1.2 & 2. & 1,2 \\
\hline AVERAGE GROSS DRY & $\mathbf{g}$ & 139.904 & 142.604 & 140.685 \\
\hline NET DAY SOLIDS & $\boldsymbol{q}$ & 0.062 & 0.227 & 0.142 \\
\hline GROSS DIGEST & 0 & 139.904 & 142.604 & 140.685 \\
\hline NET EXCESS SOLIOS & g & 0.000 & 0.000 & 0.000 \\
\hline NET DIGEST SOLIDS & 0 & 0.062 & 0.227 & 0.142 \\
\hline VOLUME DIGESTATE & $\mathrm{mL}$ & 500 & 500 & 500 \\
\hline PCS\# DIGEST SAMPLE & none & JMK133A & JMK 1338 & JMK 133C \\
\hline LABN DIGEST SAMPLE & none & S95R000001 & S95R000002 & S95R000003 \\
\hline GAOSS AESIDUE IST & D & 139.870 & 142.565 & 140.653 \\
\hline GROSS AESIDUE 2ND & a & 139.866 & 142.561 & 140.650 \\
\hline GROSS AESIDUE $3 R D$ & 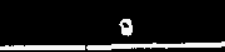 & $n / a$ & $n / a$ & $\mathrm{n} / \mathrm{a}$ \\
\hline
\end{tabular}


WHC-SD-SWF-DP-006 REV . 0

\begin{tabular}{|c|c|c|c|c|}
\hline DATUM & UNITS & CUSTOMER * 245KEB & CUSTOMER \# 246KEB & CUSTOMER * 247KEB \\
\hline RESIDUES TO AVERAGE & nono & 2. & 2, & 2. \\
\hline GROSS AVERAGE RESIDUE & g & 139.866 & 142.561 & 140.650 \\
\hline NET RESIDUE & 0 & 0.024 & 0.184 & 0.106 \\
\hline APPEARANCE RESIDUE & none & Some minuto black bits & Some minute black bits & Some minute bleck bits \\
\hline SLUDGE VOLUME & $\mathrm{mL}$ & $n / 0$ & $n / a$ & $\mathrm{n} / \mathrm{a}$ \\
\hline SLUDGE DENSITY & g/mL aludge & $n / a$ & $n / a$ & $n / a$ \\
\hline WT \% soLIDS & $\%$ of sludge & $n / \mathbf{a}$ & $n / a$ & $\mathrm{n} / \mathrm{a}$ \\
\hline WT \% WATER & $\%$ of sludge & $n / a$ & $n / a$ & $n / a$ \\
\hline SOLIOS CONC & g/mL sludgo & $\mathbf{n} / \mathbf{a}$ & $n / a$ & $n / \mathbf{a}$ \\
\hline WATER CONC & $\mathrm{g} / \mathrm{ml} \mathrm{L}$ sludge & $n / \mathbf{a}$ & $n / a$ & $n / a$ \\
\hline AVG PARTICLE DENSITY & g/mL particle & $n / a$ & $n / a$ & $n / a$ \\
\hline WT \% RESIDUE OF DIGEST & $\%$ of dry solids & $3.87 e+01$ & $8.11 e+01$ & $7.49 e+01$ \\
\hline WT $\%$ REsIDUE OF SLUDGE & $\%$ of sludge & $n / a$ & $n / a$ & $n / a$ \\
\hline LAB1 U & $\mu \mathrm{g} / \mathrm{mL}$ digest & $1.09 e+01$ & $1.220+01$ & $1.16 e+01$ \\
\hline LAB2 U & $\mu \mathrm{g} / \mathrm{mL}$ digest & $1.05 e+01$ & $1.220+01$ & $1.13 a+01$ \\
\hline LAB3 U & $\mu \mathrm{g} / \mathrm{mL}$ digost & $1.05 e+01$ & $1.21 e+01$ & $1.12 e+01$ \\
\hline LAB U DET. LIM. & $\mu \mathrm{g} / \mathrm{mL}$ digest & $3.700-04$ & $3.70 \mathrm{e}-04$ & $3.700-04$ \\
\hline LAB U BLANK & $\mu \mathrm{g} / \mathrm{mL}$ & $6.040-05$ & 6.040 .05 & $6.04 \mathrm{e}-05$ \\
\hline U RSD & $\%$ & 2.2 & 0.5 & 1.8 \\
\hline LAB U SPIKE RECOV. & $\%$ & 91.4 & $n / a$ & $n / a$ \\
\hline LAB U STD. RECOV. & $\mu \mathrm{g} / \mathrm{mL}$ & 94.8 & 94.8 & 94.8 \\
\hline U DET. LIM. & $\mu \mathrm{g} / \mathrm{mL}$ eample & $9.150-04$ & 8. $200-04$ & $8.590-04$ \\
\hline U SAMPLE 1 & $\mathrm{mo} / \mathrm{mL}$ semple & $2.700+01$ & $2.70 e+01$ & $2.69 a+01$ \\
\hline U SAMPLE 2 & $\mu \mathrm{g} / \mathrm{mL}$ sample & $2.600+01$ & $2.700+01$ & $2.62 e+01$ \\
\hline U SAMPLE 3 & ma/mL sample & $2.600+01$ & $2.68 e+01$ & $2.60 a+01$ \\
\hline U SAMPLE AVG & $\mu \boldsymbol{g} / \mathrm{mL}$ samplo & $2.630+01$ & $2.700+01$ & $2.64 e+01$ \\
\hline U SOLIDS AVG & $\mu \mathrm{g} / \mathrm{g} \mathrm{dry}$ colids & $8.58 e+04$ & $2.68 e+04$ & $4.020+04$ \\
\hline LABI $P u^{238}$ & $\mu \mathrm{ClimL}$ digost & $4.28 \mathrm{~s} \cdot 04$ & $<3.480-04$ & $4.57 e-04$ \\
\hline LAB2 Pu 238 & $\mu \mathrm{Ci} / \mathrm{mL}$ digest & $4.240-04$ & $<6.710-04$ & $<6.790-04$ \\
\hline LAB3 Pu 238 & $\mu \mathrm{Ci}, \mathrm{mL}$ digest & $4.330-04$ & $<4.280 .04$ & $<9.430-04$ \\
\hline $\mathrm{Pu}^{238}$ RSD & $\%$ & 1.1 & $n / a$ & $n / s$ \\
\hline LAB Pu ${ }^{238}$ COUNT ERROR & $\%$ & 3.7 & 6.0 & 3.7 \\
\hline $\mathrm{Pu}^{238}$ SAMPLE 1 & $\mu \mathrm{Ci} / \mathrm{mL}$ samplo & 1.060 .03 & $n / a$ & $1.060-03$ \\
\hline $\mathrm{Pu}^{238}$ SAMPLE 2 & $\mu \mathrm{Ci} / \mathrm{mL}$ sample & $1.050-03$ & $n / a$ & $n / a$ \\
\hline
\end{tabular}


WHC-SD-SNF-DP-006REV . 0

\begin{tabular}{|c|c|c|c|c|}
\hline DATUM & UNITS & CUSTOMER * 245KEB & CUSTOMER * 246KEB & CUSTOMER \# 247KEB \\
\hline $\mathrm{Pu}^{238}$ SAMPLE 3 & $\mu \mathrm{Ci} / \mathrm{mL}$ sample & $1.07 e-03$ & $\mathrm{n} / \mathrm{a}$ & $\mathrm{n} / \mathrm{a}$ \\
\hline $\mathrm{Pu}^{238}$ SAMPLE AVG & $\mu \mathrm{Ci} / \mathrm{mL}$ s ample & $1.06 e-03$ & $n / a$ & $1.06 \mathrm{e}-03$ \\
\hline $\mathrm{Pu}^{238}$ solids AVG & $\mu \mathrm{Ci} / \mathrm{g}$ dry solids & $3.450+00$ & $n / a$ & $1.61 e+00$ \\
\hline LAB1 Pu 239,240 & $\mu \mathrm{Cl} / \mathrm{mL}$ digest & $2.736-03$ & $2.65 e-03$ & $2.996-03$ \\
\hline LAB2 Pu239,240 & $\mu \mathrm{Ci} / \mathrm{mL}$ digent & $2.730-03$ & $3.046-03$ & $3.150-03$ \\
\hline LAB3 Pu 239,240 & $\mu \mathrm{Ci} / \mathrm{mL}$ digeat & $2.79 \bullet-03$ & $2.980-03$ & $2.950-03$ \\
\hline LAB Pu 239,240 DET. LIM. & $\mu \mathrm{Ci} / \mathrm{mL}$ digest & $2.400-04$ & $3.480-04$ & 2.730 .04 \\
\hline LAB Pu 239,240 BLANK & $\mu \mathrm{Ci} / \mathrm{mL}$ digest & $<5.680-05$ & $<2.598-04$ & $<7.910-05$ \\
\hline $\mathrm{Pu}^{239,240}$ ASD & $\%$ & 1.3 & 7.3 & 3.5 \\
\hline LAB Pu ${ }^{239.240}$ SPIKE RECOV. & $\%$ & 96.7 & 98.2 & 112.6 \\
\hline LAB Pu 239,240 STD. RECOV. & $\%$ & 100.0 & 89.8 & 96.9 \\
\hline LAB PU 239,240 COUNT ERAOR & $\%$ & 2.3 & 3.0 & 2.4 \\
\hline PU239,240 DET. LIM. & $\mu \mathrm{Ci} / \mathrm{mL}$ sample & $5.930-04$ & $7.716-04$ & 6.34e-04 \\
\hline $\mathrm{Pu}^{239,240}$ SAMPLE 1 & $\mu \mathrm{Cl} / \mathrm{mL}$ samplo & $6.75 \bullet-03$ & $5.870-03$ & $6.940-03$ \\
\hline $\mathrm{Pu}^{239,240}$ SAMPLE 2 & $\mu \mathrm{Ci} / \mathrm{mL}$ sample & $6.750-03$ & $6.74 \bullet-03$ & 7.310 .03 \\
\hline Pu 239,240 SAMPLE 3 & $\mu \mathrm{Ci} / \mathrm{mL}$ samplo & $6.900 \cdot 03$ & $6.600-03$ & $6.858-03$ \\
\hline $\mathrm{Pu}^{239,240}$ SAMPLE AVG & $\mu \mathrm{Ci} / \mathrm{mL}$ sample & $6.800-03$ & $6.400-03$ & $7.040-03$ \\
\hline $\mathrm{Pu}^{239,240}$ SOLIDS AVG & $\mu \mathrm{Ci} / \mathrm{s} / \mathrm{dry}$ solids & $2.22 e+01$ & $6.370+00$ & $1.07 \bullet+01$ \\
\hline U/Pu 239,240 RATIO & $\mu \mathrm{g} U / \mu(\mathrm{C}$ Pu 239.240 & $3.87 \theta+03$ & $4.21 e+03$ & $3.75 e+03$ \\
\hline
\end{tabular}

One may compare the radiochemical data in Table 3 on a dry weight basis with the data from the backwash pit campaign (Reference 4.3), and the two previous backwash Tine campaigns (References 4.4 and 4.5 ), as shown in Figures 1 to 4 . This campaign adds more information to these figures to suggest that the radiochemical content of backwash sludge is consistent with past, though highly variable, observations. 


\subsection{REFERENCES}

4.1 Internal Memo, number 95-2A100.319, C. Defigh-Price to G. L. Miller, Letter of Instruction for KE Basins Sandfilter Backwash Line Samples, Revision 1, dated August 17, 1995.

4.2 WHC-SD-NR-TRP-023, REV 1, Laboratory Test Plan for Analysis of KE Basin Backwash Pit Samples, D. B. Bechtold, November 18, 1994, Westinghouse Hanford Company, Richland, Washington.

4.3 WHC-SD-NR-TRP-021, REV 0, Report of Laboratory Test P7an for Analysis of KE Basin Backwash Pit Samples, D. B. Bechtold, March 28, 1994, Westinghouse Hanford Company, Richland, Washington.

4.4 WHC-SD-SNF-DP-002, Rev. 0, 105-K East Sandfilter Backwash Line Sample Analysis Report, First Campaign, D. B. Bechtold and G. L. Miller, November, 1995, Westinghouse Hanford Company, Richland, Washington.

4.5 WHC-SD-SNF-DP-005, Rev. 0, 105-K East Sandfilter Backwash Line Sample Analysis Report, Second Campaign, D. B. Bechtold, B. A. Crawford and G. L. Miller, December, 1995, Westinghouse Hanford Company, Richland, Washington. 
WHC-SD-SNF-DP-006 REV. 0

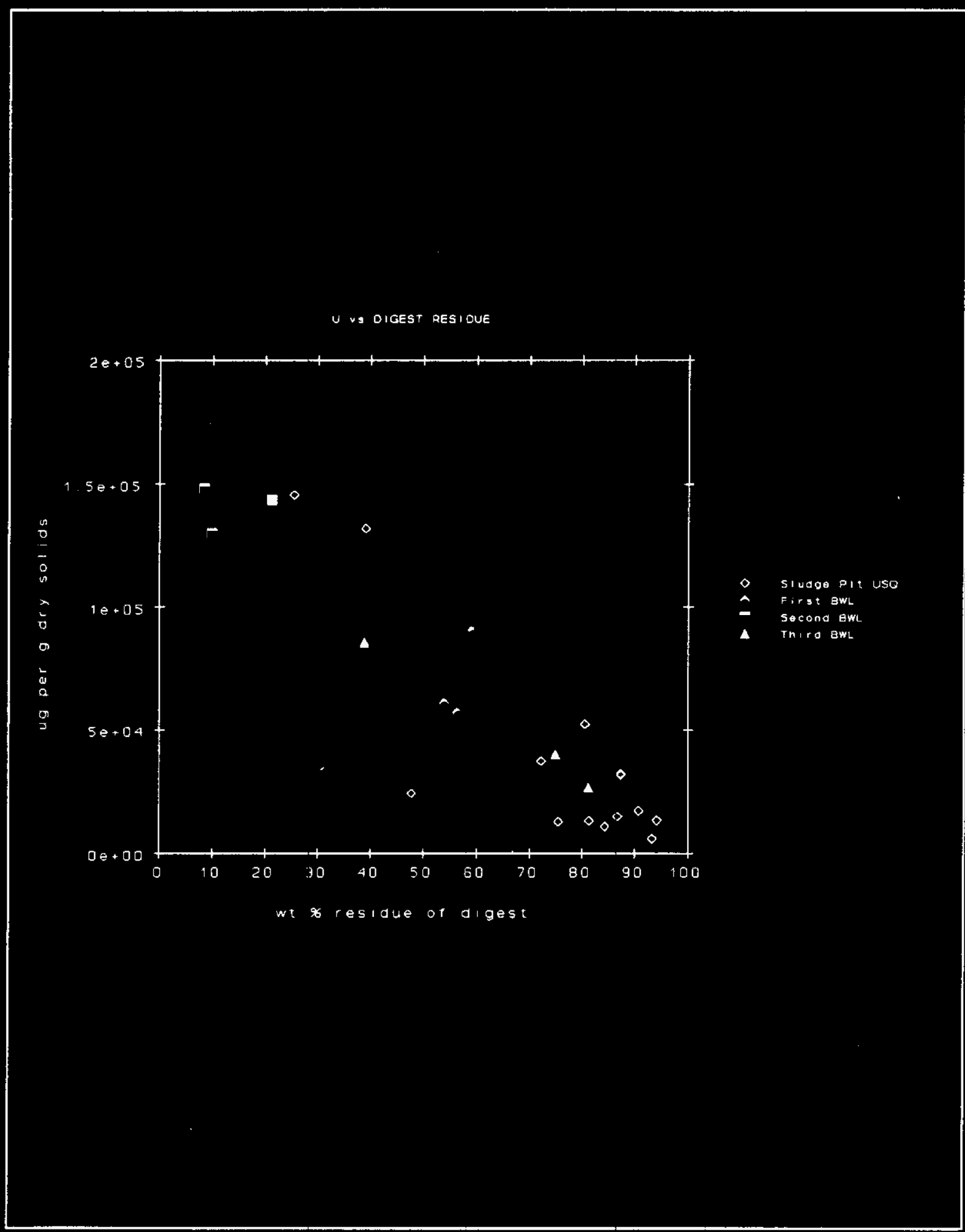

Figure 1. Uranium vs Digest Residue. 


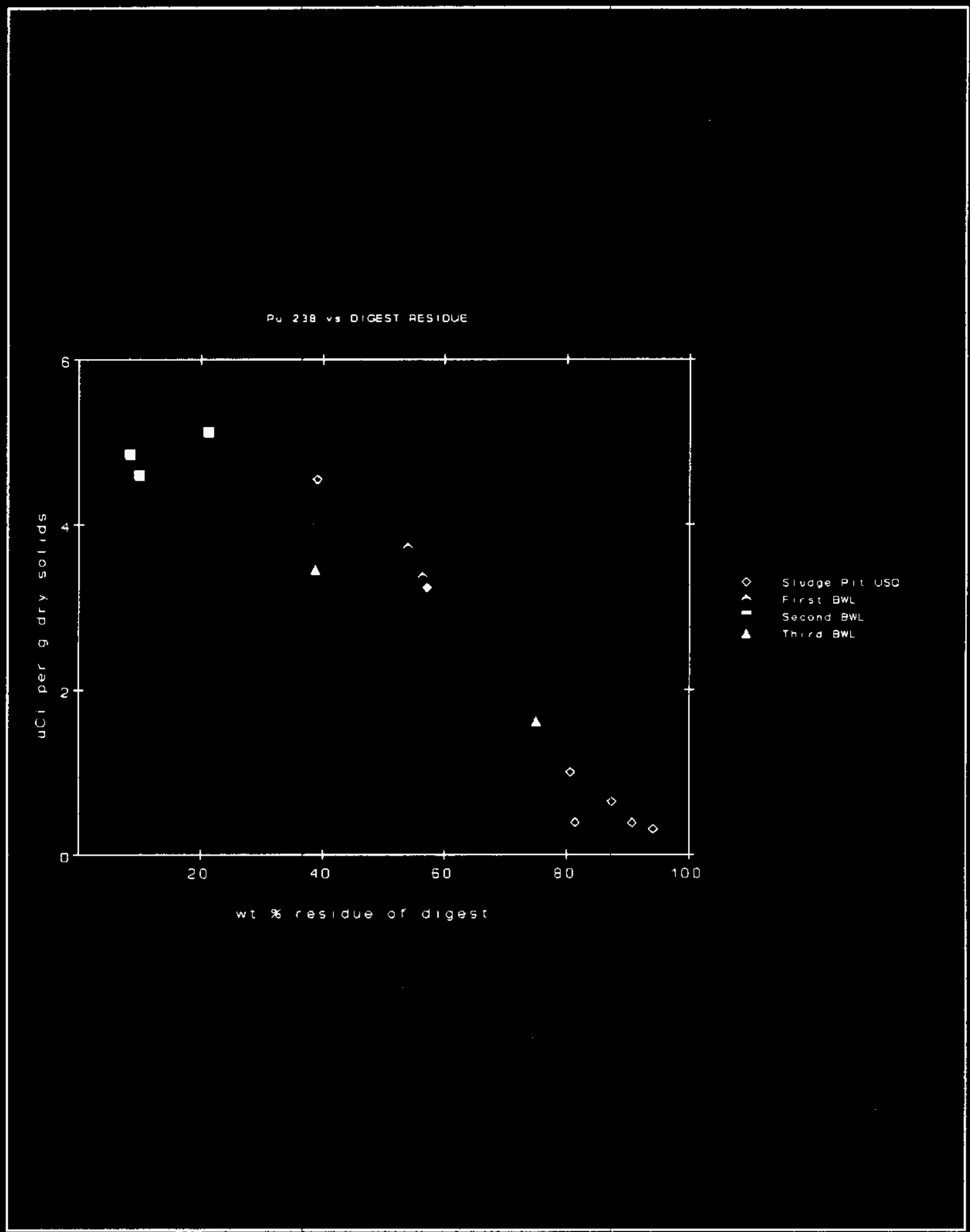

Figure 2. $\mathrm{Pu}^{238}$ vs Digest Residue. 


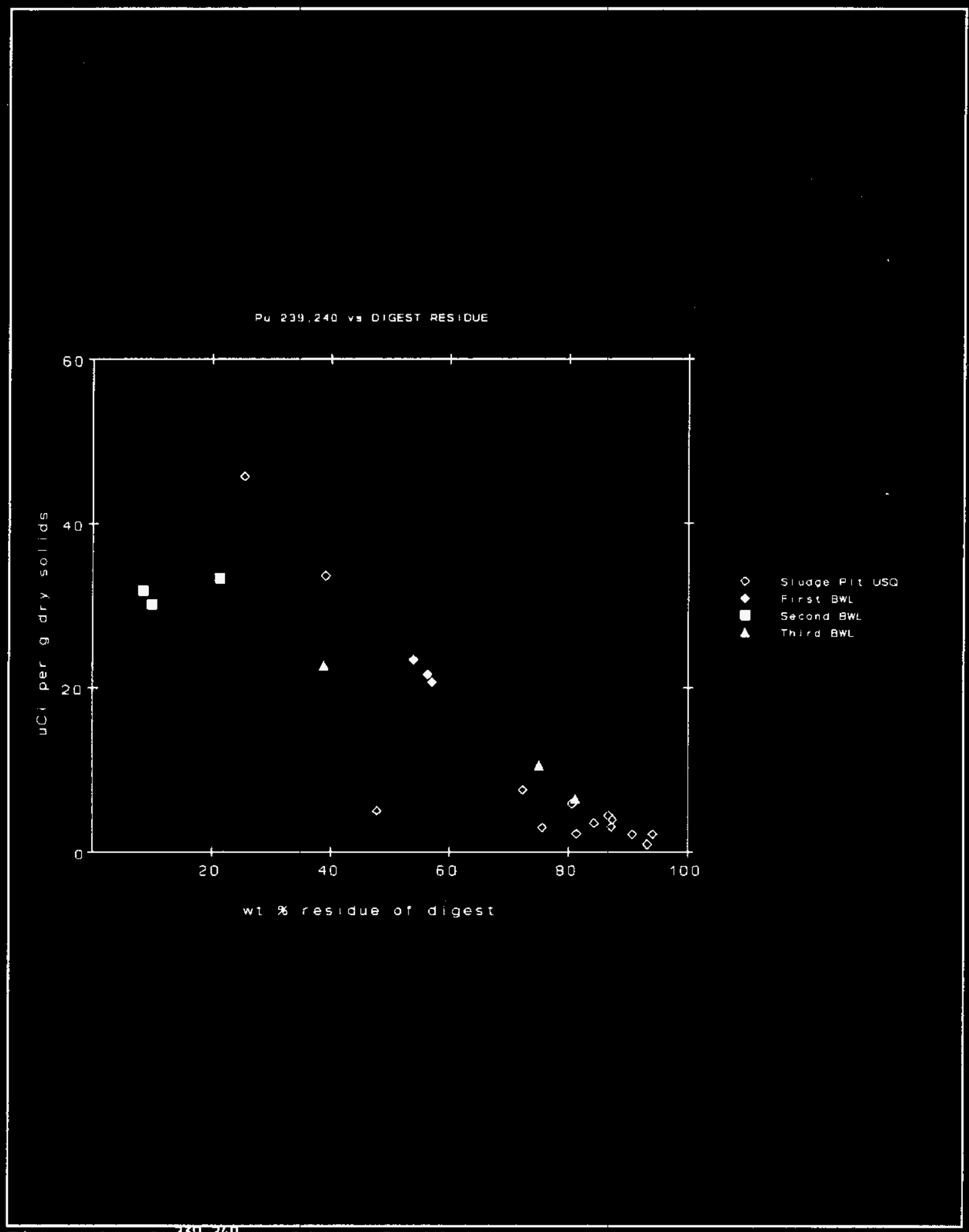

Figure 3. $\mathrm{Pu}^{239,240}$ vs Digest Residue. 


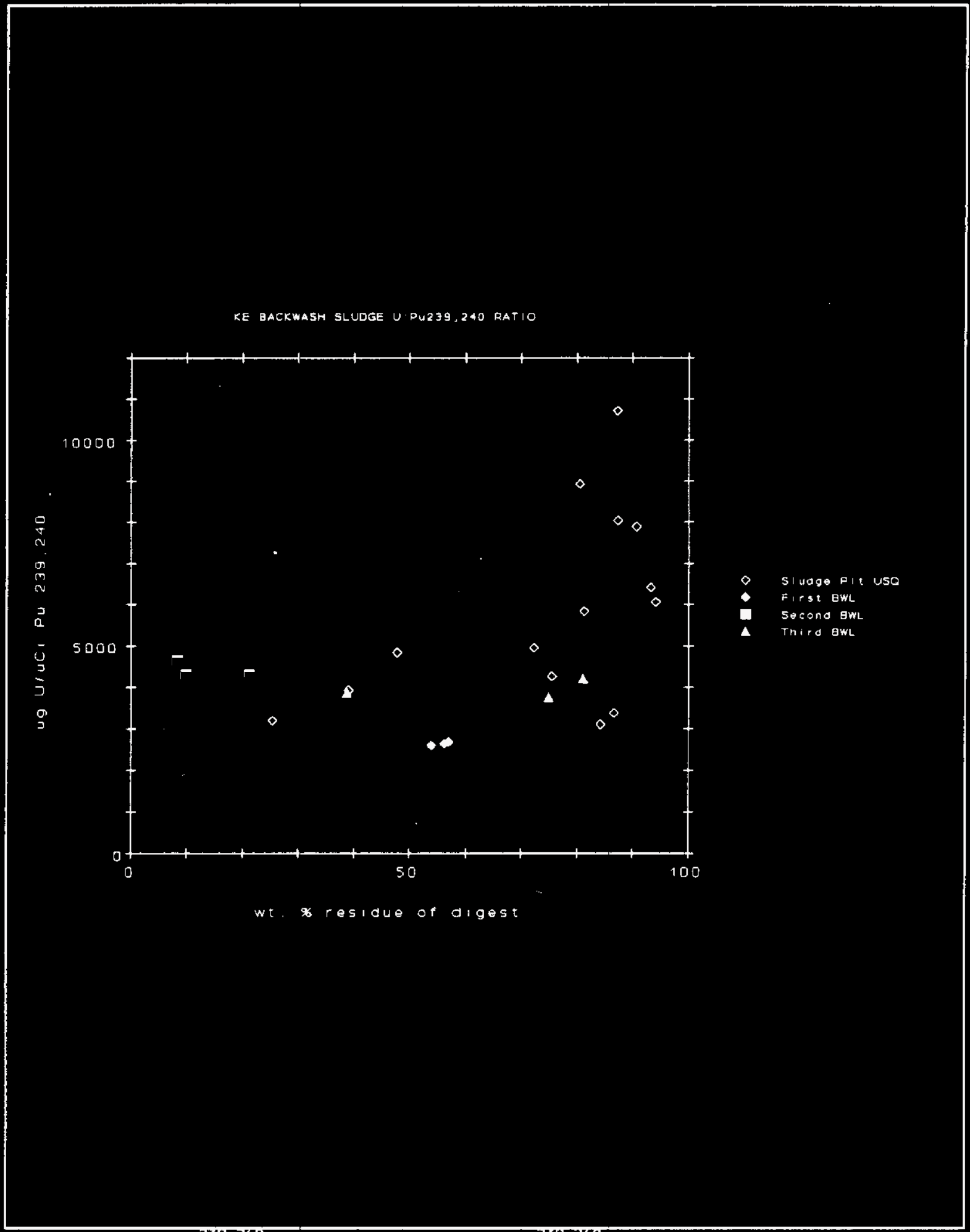

Figure 4. U: $\mathrm{Pu}^{239,240}$ Ratio ( $\left.\mu \mathrm{g} \mathrm{U} / \mu \mathrm{Ci} \mathrm{Pu}^{239,240}\right)$ vs Digest Residue. 
WHC-SD-SNF-DP-006, REV. 0

\section{APPENDIX A}

K-East Basin Sand Filter Backwash Line,

Campaign III

Activities/Concentrations of the Digested Samples 
WHC-SD-SNE-DP-006，REV . 0
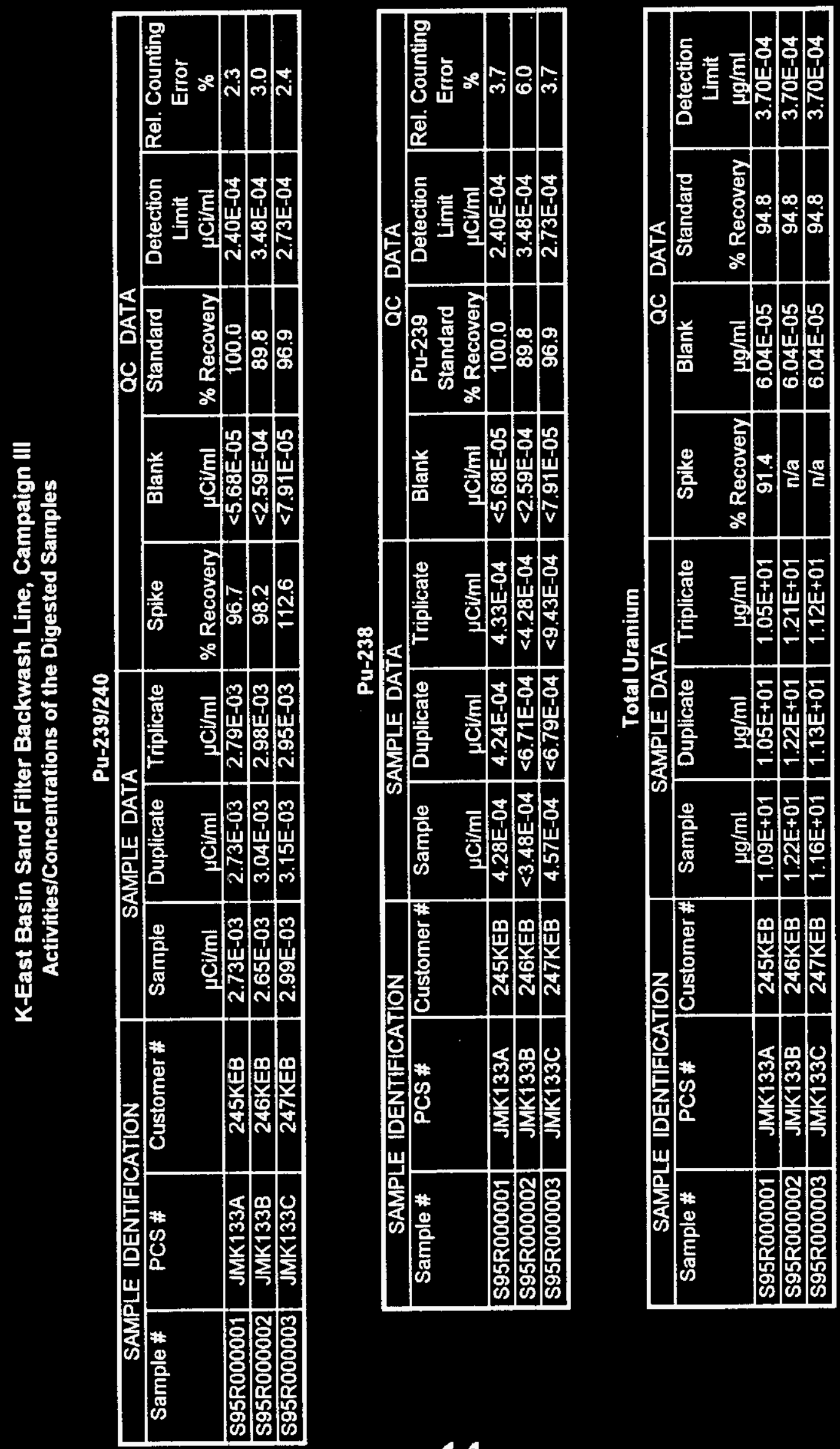
WHC-SD-SNF-DP-006, REV. 0

APPENDIX B

Chain of Custody Forms 


\section{K BASINS CHAIN OF CUSTODY}

Thain of Custody No. $21 / 445 \mathrm{KE}$ - Date $29-14-95$ Fiold Logbook No. $2 / A$ TOA\&WH Contact M.A. GRGAS Phono No. $323-1443$ MSIN $\times 3-62$

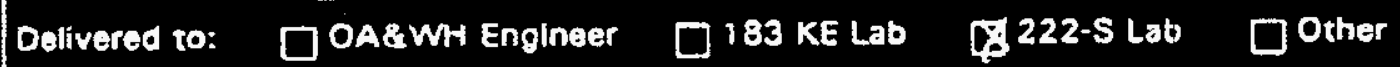
Sompled By $\frac{S C}{\text { Print }}$ OVersiate

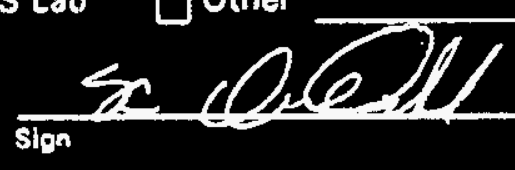

Seo Somple Anulysis Roquest for individual containers and analysis.

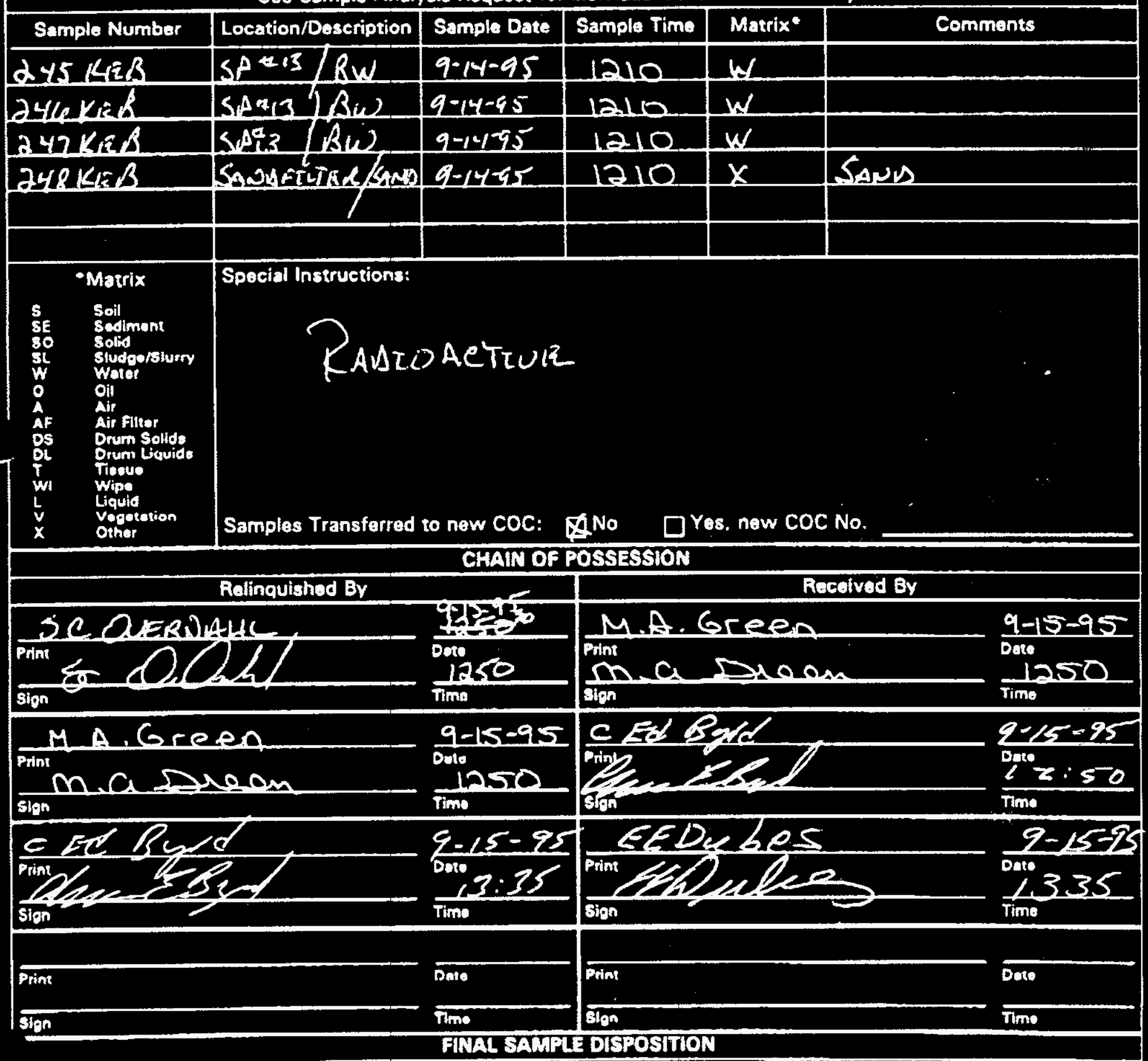

Disposal Mothod

Disposed Br: 
WHC-SD-SNF-DP-006, REV. 0

APPENDIX C

Letter of Instruction 
From: $\quad$ Standards and Requirements

Phone: $\quad 373-9596$

Date: August 17, 1995

Subject: LETTER OF INSTRUCTION FOR K BASINS SANDFILTER BACKWASH LINE SAMPLES, REVISION 1 .

To:

G. L. Miller

cc:
D. B. Bechtold
T6-09
C. L. Bennett
$\times 3-79$
S. P. Burke
$\times 3-74$
B. S. Carlisle
$\times 3-71$
G. M. Davis
$\times 3-80$
M. A. Green
$\times 3-67$
R. A. Harris
L5-01

$95-2 A 100.319$

Reference: Memo, C. DeFigh-Price to Distribution, "Letter of Instruction for KE Basins Sandfilter Backwash Line Samples, "dated June 6,1995 .

This letter and attachment constitute a complete revision of the referenced Letter of Instruction.

Samples of the material flowing into each of the $105 \mathrm{~K}$ Basin sandfilter backwash pits (SFBWP) during a backwash will be sent to the 222-S Analytical Laboratory approximately twice per year. Each shipment will contain at least three but as many as five $250 \mathrm{~mL}$ sample bottles. This work is to be charged to TCPN L11AL/Work Order E26262. This Letter of Instruction will serve as an interim Sampling and Analysis Plan for all K Basin sandfilter backwash 1 ine samples.

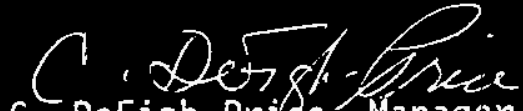

C. DeFigh-Prile, Manager

Standards and Requirements

CONCURRENCES:

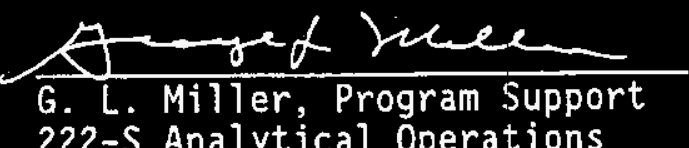

222-S Analytical Operations

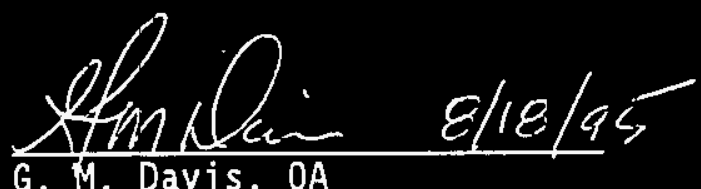

Spent Nuclear Fuel Project

jek

Attachment 


\section{INSTRUCTIONS FOR ANALYSIS OF SANOFILTER BACKWASH SAMPLES AT K-EAST FUEL STORAGE BASIN}

\section{Data Quality Objectives}

The Data Quality Objectives (DQO) are described in WHC-SD-SNF-TA-007 (Harris, 1995). The primary objective of the analytical phase of the measurements is to determine the plutonium and uranium content of the samples to the requirements indicated in Table 1. The units of the Minimum Detection Level (MDL) and Practical Quantification Limit (PQL) refer to the samples as they are received from the field. The values of the MDL and $P Q L$ applicable to actual aliquots will be different because the analyte concentrations may be increased in the drying process and/or decreased during the acid digestion process (See Instructions below.) The extrapolation of these parameters is the responsibility of the 222-S laboratory. The definitions of the parameters in the table are given in Harris, 1995.

Table 1. Analytical Parameters

\begin{tabular}{|l|c|c|}
\hline & $239 / 240 \mathrm{Pu}$ & Uranium \\
\hline $\mathrm{MDL}$ & $4.2 \mu \mathrm{Ci} / \mathrm{L}$ of sample & $23 \mathrm{mg} / \mathrm{L}$ of sample \\
\hline $\mathrm{PQL}$ & $43 \mu \mathrm{Ci} / \mathrm{L}$ of sample & $231 \mathrm{mg} / \mathrm{L}$ of sample \\
\hline Precision & $\pm 25 \%(2 \mathrm{RSD})$ & $\pm 25 \%(2 \mathrm{RSD})$ \\
\hline Accuracy & $\pm 25 \%$ & $\pm 25 \%$ \\
\hline
\end{tabular}

\section{Instructions}

The samples ( $250 \mathrm{~mL}$ bottles) will be received by the laboratory and prepared for laboratory analysis using the instructions that follow. These instructions are a modified version of preparation procedures (Bechtold 1993) that were developed to analyze samples (Warner 1994) expected to be very similar in content to the subject samples.

During sample preparation, excess water shall be removed from the samples for analysis, if specified on the chain of custody (COC) form accompanying the samples. If the COC makes no mention of this, then excess water is not to be collected or analyzed. The water samples will be analyzed for the alpha activity using the procedure shown in Table 2. It is expected that the plutonium content of the samples will be similar to that of the samples analyzed under Hunacek, 1994.

The primary analyses for the plutonium (239/240 $\mathrm{Pu}$ activity) and uranium content of the samples will utilize the procedures shown in Table 3 . Aiternate 
procedures can be substituted for those shown in both Tables 2 and 3 if approved by signature of the manager, Standards \& Requirements.

Table 2. Excess Water Procedure

\begin{tabular}{|l|l|l|}
\hline \multicolumn{1}{|c|}{ Process } & Constituent & Procedure ID \\
\hline $\begin{array}{l}\text { Internal Proportional } \\
\text { Counter }\end{array}$ & $\begin{array}{l}\text { Total } \alpha \\
\text { activity }\end{array}$ & LA-508-10I \\
\hline
\end{tabular}

Table 3. Analytical Procedures and Process Requirements for 222-S Laboratory Primary Analyses

\begin{tabular}{|c|l|l|}
\hline Process & Constituent & Procedure ID \\
\hline Separation, AEA & ${ }^{238} \mathrm{Pu},{ }^{239 / 240} \mathrm{Pu}$ & LA-943-127 \\
\hline Laser Fluorimetry & U Tota & LA-925-009 \\
\hline
\end{tabular}

\section{Analytical Quality Assurance Requirements}

The Quality Assurance (QA) requirements for the final, primary analys is of the samples are given in Table 1. The QA requirements for the sample preparation phase are listed in the following sections.

There are no requirements on the analytical parameters (MDL, PQL, precision, accuracy) for special excess water analyses since the results will be used only for qualitative screening purposes.

Precision assessments using laboratory triplicates are required for each sample. The triplicates will be taken from acid digestates resulting from the performance of the following instructions. The assessment is made by computing the standard deviation of the three triplicate samples, dividing by the mean of those three samples, and then multiplying by $2 \times 100$. If the value obtained is greater than 25 , the assessment must be rerun. If an acceptable value is not obtained after the rerun, contact Operations Analysis and Waste Handling (OA\&WH) for further direction. Every attempt should be made to obtain valid results for each of the field samples. This is because the uncertainty used in the $\mathrm{K}$ Basins Process Standard $\mathrm{C}-303$ verification analyses will be based solely on the three field samples.

Matrix spike samples for ${ }^{239 / 240} \mathrm{Pu}$ and uranium will be prepared and analyzed for each batch of samples processed. These samples require the addition of a known quantity of the analytes to the sample to measure analytical accuracy, and shall be created from the same digestate preparations used for triplicate analyses. If a spike recovery analysis differs from the expected value by more than the $25 \%$ limit, only a new spike sample will be created and analyzed 
(not the entire batch). If the rerun does not produce an acceptable recovery, OA\&WH will be notified. OA\&WH will then specify the remedial action that will be taken by the laboratory.

Laboratory data will be maintained as NQA-1 or equivalent life-of-plant (K-Basins) QA records.

\section{Reporting Requirements}

The sample preparation results will be reported on a form similar to Table 4. They will be forwarded to OA\&WH with in four weeks of receipt of the samples. The values shall be reported in the units shown in Table 4.

The primary analytical results will be forwarded to OA\&WH by electronic means within four weeks of receipt of the samples. The electronic file will be in the comma delimited format. Signed reports will be forwarded to OA\&WH within six weeks after receipt of the samples. The units of the reported results should be per $\mathrm{mL}$ of the digestate produced by the following instructions. The results for each of the triplicate samples will be provided. Only descriptions of the matrix spike runs and the resulting accuracy comparisons are required.

\section{General Preparation Instructions}

The following instructions will be used to prepare samples obtained from the backwash line at both $K$ East and $K$ West Fuel Storage Basin for analys is at the 222-S laboratory. These instructions are based on the premise that the samples will closely resemble the samples collected in 1993 (Bechtold 1993.) That is, they will consist of heavy sand underlying flocculent sludge in a water medium. The water and heavy material are not expected to contain significant amounts of the materials of interest. Special measurements to confirm the content of the water will be included as an option until no longer required. The special measurement will be performed only if requested on the chain of custody (COC) form accompanying the samples.

In general, the sample preparation steps that evolved with the 1993 analyses will be followed (Bechtold 1993.) These steps are:

- remove the excess water over the settled sludge and dry it,

- acid digest the dried sludge, and

- sub-sample the digestate for the required component analyses.

It is very important to determine the weight and volumes of the materials and vessels both before and after each step in this preparation so that the final results can be related back to the original sample volume. Some exceptions to the 1993 test procedure were necessary. The major ones are listed below.

- No consolidation of a sample into a single container will be required because each will arrive at the laboratory in a single bottie. 
WHC-SD-SNE-DP-006, REV. 0

- The volume of the original sample must be recorded because the laboratory results must be converted to $\mathrm{mL}$ of the original sample rather than to $\mathrm{mL}$ of sludge.

These exceptions require minor but numerous changes to the test procedure steps. Rather than refer to the 1993 test procedure and indicate each change, the steps appropriate for these analyses have been extracted. If there is any confusion about the meaning or context of these extracted steps (given below) the analyst should refer to the original (Bechtold 1993.)

The data that must be recorded during the preparation of the samples are summarized on Table 4. The data should be reported on this form or a similar one containing the information indicated.

Table 4. Sample Preparation Data

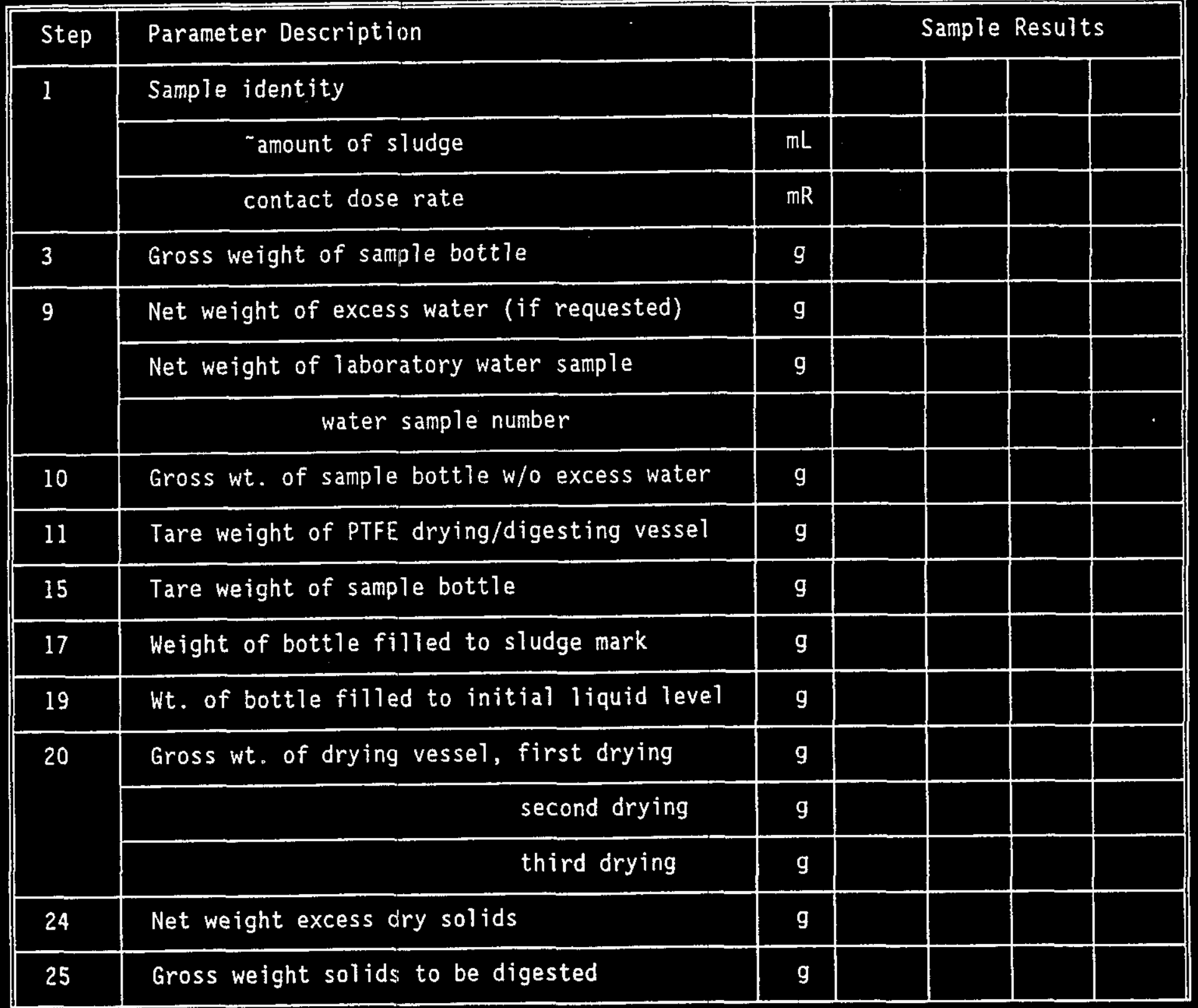




\begin{tabular}{|l|l|c|c|c|c|c|}
\hline Step & Parameter Description & & \multicolumn{3}{|c|}{ Sample Results } \\
\hline 40 & Volume of diluted digestate & $\mathrm{mL}$ & & & & \\
\hline 44 & Gross weight of dry digester plus residue & $\mathrm{g}$ & & & & \\
\hline & second digestion & $\mathrm{g}$ & & & & \\
\cline { 2 - 7 } & Appearance of dried residue & $\mathrm{g}$ & & & & \\
\hline 46 & & & & & & \\
\hline
\end{tabular}

The precision and accuracy requirements for the data collected with these instructions (listed in Table 4) are given in Table 5.

Table 2. Data Precision and Accuracy Requirements

\begin{tabular}{|c|c|c|}
\hline Datum & Precision & Accuracy \\
\hline Sludge 0bservations & qualitative & qual itative \\
\hline $\begin{array}{c}\text { sludge height mark }(s) \\
\text { initial water level mark } \\
\text { (original sample volume) }\end{array}$ & $\pm 10 \%$ of total height & $\pm 10 \%$ of total height \\
\hline $\begin{array}{c}\text { all weights (dry and } \\
\text { liquid) }\end{array}$ & $\begin{array}{c} \pm 0.1 \mathrm{~g} \text { (scale } \\
\text { accurate to } 0.025 \mathrm{~g})\end{array}$ & $\pm 3 \%$ of total height \\
\hline digestate volume & $\begin{array}{c}\text { volumetric glassware } \\
\text { precision }\end{array}$ & $\begin{array}{c}\text { volumetric glassware } \\
\text { accuracy }\end{array}$ \\
\hline
\end{tabular}

\section{PROCEDURE STEPS}

"Drying to constant weight" in the following steps means attaining two successive weights whose difference is no more than $0.1 \%$ of the lowest calculated net weight of the two.

Hold points in the following steps are documented as released by a logged statement "Step _ released" followed by the signature of the responsibie scientist.

Perform the following steps for each sample, recording all data and observations in a controlled laboratory notebook. 
1. Examine all samples as-delivered by temporarily loading them one at a time into a radioactive service hood. Record each sample identity, approximate amounts of sludge, and contact dose rates in order to judge the need for hot cell facilities and to size the needed labware.

2. Load the sample into the hood or hot cell, whichever is appropriate, recording the sample identity.

3. Weigh and record the gross weight of the sample bottle.

4. Mark the sample bottle indelibly at the top of the liquid level. This is an important measurement that directly affects the ultimate use of the laboratory data. The bottle must be level and the mark must be made planar with bottom of meniscus. Note that the configuration of the bottle for this measurement must be as close as possible to that used in step 18.

5. Allow the sample bottle contents to settle in a level spot for a minimum of 24 hours and record the actual settling time.

6. Observe the sample bottle contents to verify the existence of a discernable boundary between the water and sludge.

NOTE: Step 7 is a HOLD POINT to await the determination of a water/sludge boundary.

7. Mark the sample bottle indelibly at the top of the sludge.

8. Vacuum suction off the excess water above the sludge in the sample bottle to a separate container without removing any sludge.

9. If specifically requested on the $\mathrm{COC}$ form, record the total weight of the excess water arid create, weigh, and number a sample of the excess water. Perform a total alpha analysis on this sample. Retain the remaining excess water. Do not retain the excess water unless sampling was requested on the $\mathrm{COC}$ form.

10. Weigh and record the weight of the sample bottle without the excess water.

11. Weigh and record the tare weight of a suitably sized polytetrafluoroethylene (PTFE) drying/digesting vessel.

12. Quantitatively transfer the sample bottle's contents to the drying vessel, using a stirrer and rinsing with laboratory deionized water as necessary.

13. Place the drying vessel on a clean hot plate, along with a ventilating cover over the drying vessel to prevent dirt settling into it, and commence drying at a heat setting which produces approx. $120^{\circ} \mathrm{C}$ temperature at the contents when they are dry for at least 2 hours.

14. While drying the sludge solids, rinse clean and dry the empty sample bottle. 
WHC-SD-SNF-DP-006, REV. 0

15. Weigh and record the tare weight of the empity sample bottle.

16. Add laboratory deionized water to the sludge height mark made in step 7.

17. Weigh and record the weight of the sample bottle plus laboratory deionized water.

18. Add laboratory deionized water to the initial liquid level mark made in Step 4. Be sure to have bottle level, and bring the bottom of the meniscus planar to the mark.

19. Weigh and record the weight of the sample bottle plus laboratory dejonized water.

20. After drying the drying vessel and its contents for a suitable time interval (at least two hours), cool, reweigh and record the weight of the drying vessel and contents.

21. Thoroughly mix the drying vessel contents with the stirrer.

22. Repeat Steps 20. and 21. at least once, and as many times as necessary to come to a constant weight.

23. Obtain a suitable, labeled storage jar.

NOTE: Step 24 is a HOLD POINT to determine if there are sufficient dried solids present to divide into two portions.

24. Weigh out of the dryer/digester the excess dry solids over approximately 10 grams, if any, putting the excess into the storage jar, and leaving up to approximately 10 grams in the dryer/digester to be digested.

25. Record the new gross weight of the solids to be digested in the dryer/digester.

26. Obtain a suitable number of centrifuge cones with caps for use in clarifying digestates.

NOTE: Approximately 10M aqueous HCl may be conveniently prepared by carefully mixing concentrated hydrochloric acid reagent and laboratory deionized water at the rate of $1 \mathrm{~mL}$ acid per $0.245 \mathrm{~mL}$ water.

NOTE: Approximately $10 \mathrm{M}$ aqueous $\mathrm{HNO}_{3}$ may be conveniently prepared by carefully mixing concentrated nitric acid reagent with laboratory deionized water at the rate of $1 \mathrm{~mL}$ acid per $0.6 \mathrm{~mL}$ water.

27. Prepare a digesting reagent consisting of (by volume) 1 part approximately $10 \mathrm{M}$ aqueous $\mathrm{HCl}$ and 1 part approximately $10 \mathrm{M}$ aqueous $\mathrm{HNO}_{3}$.

28. Select a volumetric flask large enough to accommodate all clear digestate and subsequent rinsings of Steps 29 . through 40. , but no larger than 2 Liter capacity.

29. Add digesting reagent to the digesting vessel plus dry solids at the minimum rate of 2 volumes reagent per volume dry solids, but no more 
than the digesting vessel can comfortably handle, and can be quantitatively transferred later.

30. Add concentrated HF to the digesting vessel at the rate of $1-2$ drops concentrated HF per $100 \mathrm{~mL}$ of digesting reagent added.

31. Digest the solids by heating to near-boiling on the hot plate for four hours with a ventilating cover over the digester, adding digesting reagent as necessary to maintain volume.

32. Allow the digestate to cool and settle.

33. Decant the digester liquid, as much as will drain from the residues, into the cones.

34. Rinse the residues three times with acid, decanting the rinses into the cones each time.

35. Centrifuge the digestate/rinsates for 15 minutes.

36. Decant the clarified digestate into the volumetric flask, being carefu? to retain any residues in the cones.

37. Perform the following lettered sequence three times to rinse the cones:

a. Rinse down the cones with acid.

b. Centrifuge 15 minutes.

c. Decant into the volumetric flask.

38. Mix the volumetric flask contents.

39. Rinse the residue from the cones back into the digester, using fresh digestion reagent as necessary, and Repeat Steps 29. through 38. to effect a second digest.

CAUTION: Addition of water to the digestate will generate large amounts of heat, enough to cause bumping in the volumetric flask if care is not taken. Add water slowly.

40. Slowly add laboratory deionized water to the volumetric flask while mixing by swirling, dilute to volume, thoroughly mix, and record the volume.

41. Rinse the residue from the cones back into the digester using laboratory deionized water as necessary.

42. Heat the digester with a ventilating lid on the hot plate to drive off the liquid and dry the residue at least two hours thereafter, using a setting which will produce approximately $120^{\circ} \mathrm{C}$ temperature in the dry residue.

43. Cool the digester. 
44. Weigh and record the gross weight of the dry digester and residue.

45. Repeat Steps 42. through 44. at least once, and as many times as are required to come to a constant gross weight.

46. Observe and record the appearance of the dried residue. Dispose of the dried residue.

47. Withdraw a labeled, recorded al iquot of the volumetrically diluted digestate and submit to 222-S Analytical Operations for analyses.

48. Label and record the remainder of the volumetrically diluted digestate. This sample will be retained until released by K-Basin Operations.

49. Store all labeled portions of dry solids, digestate and dry residue.

50. Clean the work space, prepare reagents and equipment for the next sample.

\section{REFERENCES}

R. A. Harris, "Surveillance and Prediction Methods for the Plutonium Limit in the K East Fuel Storage Basin Sandfilter Backwash Pit," WHC-SD-SNF-TA-007, Revision 0 , dated 1995 .

G. S. Hunacek, Jr., "105 KE Fuel Storage Basin, Sampling and Analysis Plan," WHC-SD-NR-PLN-014, Revision 0, dated 1994.

R. D. Warner, "Safety Evaluation of the Plutonium and Uranium Content of the K East Basin Sandfilter Backwash Pit," WHC-SD-WM-TA-152, Revision 0, dated 1994.

D. B. Bechtold, "Laboratory Test Plan for Analys is of KE Basin Backwash Pit Samples," WHC-SD-NR-TP-023, Revision 1, dated 1993.

D. B. Bechtold, "Laboratory Test Plan for Analys is of KE Bas in Backwash Pit Samples," WHC-SD-NR-TP-023, Revision 1, dated November 18, 1993. 


\section{DISTRIBUTION SHEET}

\begin{tabular}{|c|c|c|c|}
\hline \multirow{2}{*}{$\begin{array}{l}\text { To } \\
\text { Distribution }\end{array}$} & \multirow{2}{*}{\multicolumn{2}{|c|}{ From Production Planning and Control }} & Page 1 of 1 \\
\hline & & & $12 / 20 / 95$ \\
\hline \multirow{2}{*}{\multicolumn{2}{|c|}{$\begin{array}{l}\text { Project Title/Work Or } \\
\text { WHC-SD-SNF-DP-006, Re } \\
\text { Sample Analys is Repor }\end{array}$}} & \multirow{2}{*}{ ackwash Line } & EDT NO. : 614765 \\
\hline & & & ECN NO.: N/A \\
\hline & MSIN & $\begin{array}{l}\text { Text With } \\
\text { all Attach }\end{array}$ & $\begin{array}{l}\text { EDT/ECN } \\
\text { ONLY }\end{array}$ \\
\hline
\end{tabular}

Westinghouse Hanford Company
R. B. Baker
C. L. Bennett
S. T. Burke
C. Defigh-Price
J. L. Deichman
M. A. Green
R. A. Harris
M. A. Jensen
C. D. Lucas
G. L. Miller
Central Files
EDMC
LTIC
TCRC
A Traiger

$\begin{array}{lll}\begin{array}{l}\text { L5-01 } \\ \text { X3-79 }\end{array} & X & \\ \text { X3-74 } & X & \\ \text { X3-79 } & X & \\ \text { T6-03 } & X & \\ X 3-67 & & \\ \text { L5-01 } & X & \\ \text { X3-79 } & X & \\ \text { X3-67 } & X & \\ \text { T6-06 } & X & \\ \text { A3-88 } & 2 & \\ \text { H6-08 } & X & \\ \text { T6-03 } & & \\ \text { R2-12 } & X & \\ X 3-85 & X & \end{array}$

